\title{
TOWARDS CLUSTERS' PERFORMANCE EVALUATION: THE SYSTEM OF INDICATORS
}

\author{
Kristina Razminiené $\dot{1}^{1}$, Manuela Tvaronavičiene் ${ }^{2}$ \\ ${ }^{1,2}$ Department of Business Technologies and Entrepreneurship, Faculty of Business Management, \\ Vilnius Gediminas Tevhnical University, Vilnius, Lithuania \\ E-mails: ${ }^{1}$ kristina.razminiene@vgtu.lt (corresponding author); ${ }^{2}$ manuela.tvaronaviciene@vgtu.lt
}

\begin{abstract}
This paper is composed to specify the indicators identified by scholars used for cluster performance, efficiency or competitiveness assessment. Traditional bibliometric technique was chosen to identify the trends in cluster literature. Articles from the Web of Science database were selected according to the times they were cited which allowed systemizing the aspects of the research and making valuable observations. A system of indicators which should get the most attention in cluster research was composed identifying exceptionally important points to discuss and include in the following studies. In the national level clusters usually are not able to compare their performance for there is no system created to serve this purpose. The close analysis of the indicators of cluster performance would enable cluster evaluation tool formation for cluster performance evaluation in national level.
\end{abstract}

Keywords: cluster, proximity, indicators, innovations, R\&D, performance, competitiveness, knowledge transfer.

JEL Classification: R11.

\section{Introduction}

The interest in clusters is growing since Marshall (1920) has first described industrial districts as a socio-economic notion, where geographic location is important for growth, competitiveness and agglomeration patterns of regions (Li, Veliyath, \& Tan, 2013; Tanner, 2014; Zheng, 2011). The term 'industrial district' is strongly associated with the term 'cluster' which was elaborated by Porter (1990) who is in most cases referred as a founder of the term and refers to cluster as "geographic concentrations of interconnected companies and institutions in a particular field". Competitiveness is emphasized as well as cooperation of companies as it can be stimulated in clusters by increasing business productivity, innovation capacity and stimulating the formation of new business, which also adds to expanding and strengthening of a cluster. Industrial districts and clusters are often used interchangeably in research papers as they both emphasize the importance of geographical proximity as a competitive advantage of companies.

Scholars are analysing clusters and cluster literature in different aspects and employing various techniques for the multidisciplinary nature of the subject which makes it hard to trace the changing themes in cluster analysis (Dobrovolskiene,
Tvaronavičienè, \& Tamošiūnienè, 2017; Tvaronavičiené, 2017; Razminienè \& Tvaronavičienè, 2017; Monni, Palumbo, \& Tvaronavičienè, 2017; Tvaronavičienè \& Razminiené, 2017; Yang \& Černevičiūtè, 2017; Prause \& Atari, 2017; Fuschi \& Tvaronavičienè, 2016). Literature analysis usually depends on traditional direct citation counts and co-citation analysis (Lazzeretti, Sedita, \& Caloffi, 2014; Tvaronavičienè, Razminienè, \& Piccinetti, 2015) which in general are past oriented but can help to trace emerging themes or identify the shortage of attention to some aspects worth more examination.

This paper positions itself at the interest of cluster field relying on traditional methods of analysis. Bibliometric technique was chosen to identify the trends in clusters' literature. Indicators of cluster performance is the main interest in this paper as well as emerging topics or lines. The attempt is to compare cluster literature which was selected by the author using traditional bibliometric technique and systemize it according to the indicators identified by scholars used for cluster performance, efficiency or competitiveness assessment.

The purpose of the study is to identify the indicators that are used in the literature of cluster analysis. 
The article is structured as follows. Section 2 describes the research design and the method of data collection. Section 3 illustrates the results of literature analysis of the cluster viewed from the indicators perspective. Finally, Section 4 incorporates the conclusive remarks.

\section{Data and methodology}

The articles that were used for literature analysis in this research paper were found at the Web of Science database. This database was chosen for it contains the world's leading scholarly literature in different categories. 50 articles were selected from this database according to the times they were cited which allowed systemizing the aspects of the research and making valuable observations.

There were some restrictions applied while selecting the articles. Cluster as a keyword works for different categories and can be used in various fields. For this reason, the search must have been restricted to some extent and articles revised after final search results were suggested. At first, research papers that belong to the Web of Science categories, such as business, geography, economics and management, urban studies, environmental studies were selected. Later, the search was refined by publication years from 2013 to 2017 which resulted in 4051 publications. Then, research areas were clarified to business economics, geography, urban studies and international relations. After these steps the final requirement was to select 50 research papers which were cited 8 times at least (see Table $1)$.

Table 1. Citation report (source: composed by authors)

\begin{tabular}{|l|c|}
\hline \multicolumn{1}{|c|}{ Results found } & 50 \\
\hline Sum of the Times Cited & 768 \\
\hline Sum of Times Cited without self-citations: & 759 \\
\hline Citing Articles & 691 \\
\hline Citing Articles without self-citations & 683 \\
\hline Average Citations per Item & 15.36 \\
\hline
\end{tabular}

The results set was chosen after close inspection to make sure the articles comply with the aim of this article and can add important aspects for further research. The sum of the times cited in the Table 1 applies to the total number of citations to all of the articles found in the results set. Next field displays the total number of citations to all of the items found in the results set minus any citation from articles in the set. The citing articles and citing articles without self citation show the imformation about the selection of the authors of research papers. Average citations per item are calculated using a simple formula that calculates the average number of citing articles for all items in set.

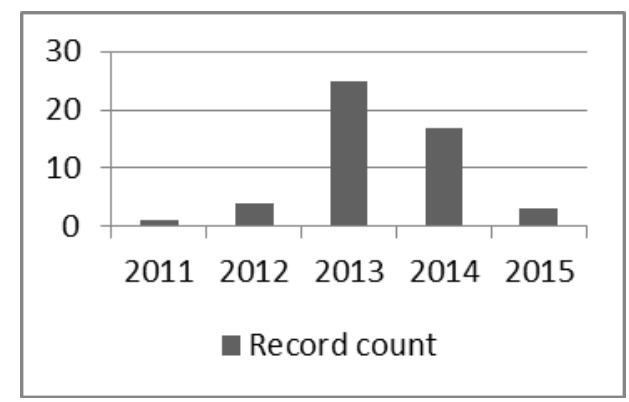

Figure 1. Results analysis by publication years (composed by authors)

Figure 1 presents the number of articles that were published in the selected period. The greatest number of articles which comply to the topic of the research with the relevant rate of citations was in years 2013. The tendency shows the growing interest in the field of cluster research.

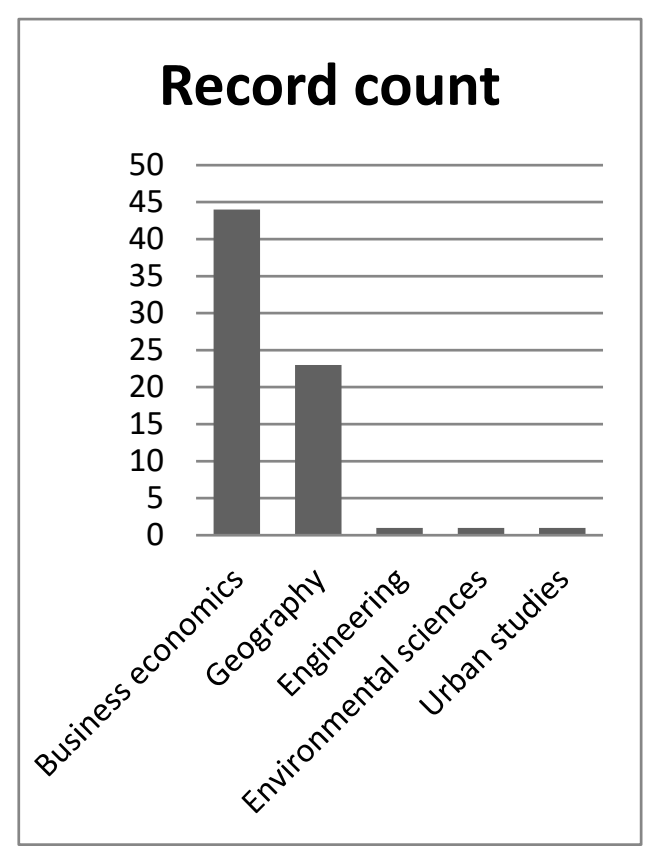

Figure 2. Results analysis by research areas (composed by authors)

The greatest number of articles belongs to business economics as a research area which shows the importance of the topic (see Figure 2). Geography takes one third of all the articles that were chosen for literature analysis and the small- 
est part goes to engineering, environmental sciences and urban studies.

Traditional bibliometric technique was chosen to identify the trends in cluster literature. It becomes more difficult to track the recent trends of topics in clusters literature the number of which is growing exponentially. Scholars, who presented their works on literature review aiming at tracing intellectual origins, producing a history of founders or highlighting the most-cited papers usually use direct citation counts and co-citation analysis (Crane, Palazzo, Spence, \& Matten, 2014; Hervas-Oliver, Gonzalez, Caja, \& Sempere-Ripoll, 2015). In this paper, direct citation counts was identyfied as an appropriate technique which enables to fulfill the main aim of the research, which is to identify the indicators that are used in clusters' research for clusters' performance evaluation model further modelling.

Literature analysis allowed identyfying different aspects that are viewed by sholars in clusters' analysis and as a result 9 groups of indicators were structured, namely: proximity, innovation, knowledge, networking, financial indicators, investition indicators, government indicators, resource indicators and that of sustainability. These groups are given later in the paper with authors and main points ascribed to them as from literature review.

\section{The indicators of clusters' performance as viewed in scientific literature}

Close literature analysis allowed identifying the indicators that are discussed in research papers when clusters are perceived from the scientific point of view. Here, indicator is used to describe a group of elements, either concrete or abstract, which may serve for selection of smaller units in creating a model of cluster performance measuring. Nine groups of indicators were identified as having a significant value in further formation of clusters' performance evaluation model. These indicators are viewed through identification of authors that have perceived their importance and some general observations marked for deeper understanting of the matter.

The first group of indicators was formed as proximity indicators. Schollars view it as having different impact on clusters' performance (see Table 2).

According to Ben Letaifa and Rabeau (2013), geographic proximity is worth the attention that it gets for it enables collaboration and innovation. However, some clusters still fail to
Table 2. 1st group of indicators as viewed by scholars in scientific literature - proximity (composed by authors)

\begin{tabular}{|c|c|}
\hline Authors & Indicator - proximity \\
\hline $\begin{array}{l}\text { Letaifa and } \\
\text { Rabeau } \\
(2013)\end{array}$ & $\begin{array}{l}\text { The stress is put on interaction } \\
\text { among geographic, institutional, } \\
\text { organizational, cognitive and } \\
\text { social proximities. }\end{array}$ \\
\hline $\begin{array}{l}\text { Bindroo, Mar- } \\
\text { iadoss, and } \\
\text { Pillai (2012) }\end{array}$ & $\begin{array}{l}\text { Customer cluster proximity's } \\
\text { importance on firm innovation. }\end{array}$ \\
\hline $\begin{array}{l}\text { Boschma, } \\
\text { Minondo, and } \\
\text { Navarro } \\
(2013)\end{array}$ & $\begin{array}{l}\text { Regional capabilities may show } \\
\text { the tendency of new industries to } \\
\text { be developed in regions }\end{array}$ \\
\hline $\begin{array}{l}\text { Carswell } \\
(2013)\end{array}$ & $\begin{array}{l}\text { A 'horizontal' approach with } \\
\text { social networks and vertically } \\
\text { linked production networks }\end{array}$ \\
\hline $\begin{array}{l}\text { Casanueva, } \\
\text { Castro, and } \\
\text { Galan }(2013)\end{array}$ & $\begin{array}{l}\text { How social networks impact the } \\
\text { transition of tacit and explicit } \\
\text { knowledge. }\end{array}$ \\
\hline $\begin{array}{l}\text { Castellani, } \\
\text { Jimenez, and } \\
\text { Zanfei (2013) }\end{array}$ & $\begin{array}{l}\text { The importance of geographical } \\
\text { proximity }\end{array}$ \\
\hline $\begin{array}{l}\text { Crespo, Suire, } \\
\text { and Vicente } \\
(2014)\end{array}$ & $\begin{array}{l}\text { Regional resilience through local } \\
\text { knowledge sharing. }\end{array}$ \\
\hline $\begin{array}{l}\text { D’Este, Guy, } \\
\text { and Iam- } \\
\text { marino (2013) }\end{array}$ & Geographical proximity \\
\hline $\begin{array}{l}\text { Fallah, Par- } \\
\text { tridge, and } \\
\text { Rickman } \\
\text { (2014) }\end{array}$ & $\begin{array}{l}\text { Proximity to a research universi- } \\
\text { ty and proximity in the urban } \\
\text { hierarchy. }\end{array}$ \\
\hline Funk (2014) & Local environments \\
\hline $\begin{array}{l}\text { Helsley and } \\
\text { Strange } \\
(2014)\end{array}$ & $\begin{array}{l}\text { Agglomerative efficiencies for } \\
\text { the size and composition of cities }\end{array}$ \\
\hline $\begin{array}{l}\text { Schmitt and } \\
\text { Van } \\
\text { Biesebroeck } \\
\text { (2013) }\end{array}$ & $\begin{array}{l}\text { The relative importance of three } \\
\text { dimensions: geographical, cultur- } \\
\text { al and relational proximity }\end{array}$ \\
\hline $\begin{array}{l}\text { Alcacer and } \\
\text { Chuang } \\
(2014)\end{array}$ & $\begin{array}{l}\text { What impact does location have } \\
\text { on company's competitive ad- } \\
\text { vantage? }\end{array}$ \\
\hline $\begin{array}{l}\text { Basile, Ben- } \\
\text { fratello, and } \\
\text { Castellani } \\
(2013)\end{array}$ & $\begin{array}{l}\text { Location determinants of inward } \\
\text { greenfield investments in regions } \\
\text { are studied. }\end{array}$ \\
\hline $\begin{array}{l}\text { Zhu, He, and } \\
\text { Liu (2014) }\end{array}$ & $\begin{array}{l}\text { Geographical relocation, out- } \\
\text { sourcing and plant closure. }\end{array}$ \\
\hline $\begin{array}{l}\text { Alcacer and } \\
\text { Chuang } \\
(2014)\end{array}$ & $\begin{array}{l}\text { Localization and concentration of } \\
\text { three points that both supply and } \\
\text { demand sides of agglomeration } \\
\text { economies must be examined. }\end{array}$ \\
\hline
\end{tabular}


collaborate in spite of their geographical proximity. The study is based on the examination of a cluster which fails to collaborate and the stress is put on interaction among geographic, institutional, organizational, cognitive and social proximities. The findings suggest that the most important proximity in collaboration achievements is social proximity and geographic proximity can even be harmful for it may prevent social proximity. What is more, geographic distance may have positive effect on entrepreneurship and innovation. Naturally formed clusters with private entrepreneurial initiatives are more progressive in innovations than those created by economic policies.

Garment cluster in South India was taken to prove that labour should get more attention by Carswell (2013) in global production networks with empirical and analytical studies. A 'horizontal' approach with gender, age, caste and regional connections taken into account is employed to reveal how social relations and livelihood strategies are relevant in comparison to vertically linked production networks. Here effects on workers' livelihoods, social relations and reproductive capacities are discussed as helping to shape local developments of global capitalism.

D'Este et al. (2013) are interested in collaboration between universities and industry as they are considered to be an important channel of potential localized spillovers. According to the article, the factors that are responsible for universities and industry collaboration, especially geographical proximity do not get enough attention from researchers and interested parties. For this reason, authors share their ideas of how clustering and technological complementarity among the firms in partnership contribute to the formation of university and industry research collaborations.

European automotive industry was used as a case to investigate the trends that affect manufacturing of sophisticated goods (Schmitt \& Van Biesebroeck, 2013). It is noted that the importance in proximity in the supply chain is growing recently. The relative importance of three dimensions: geographical, cultural and relational proximity was evaluated in the study. The results show that some aspects of proximity are valued in companies' sourcing strategy.

The second group of indicators is innovation. This group is naturally viewed as having significant impact on clusters' performance, although special attention should be paid to the kind of innovations that are implemented in clusters' activities. A closer stufy on innovation would be very necessary for recommendation formation while creating a model of clusters' performance evaluation (see Table 3 ).

Table 3. 2nd group of indicators as viewed by scholars in scientific literature - innovation (composed by authors)

\begin{tabular}{|l|l|}
\hline \multicolumn{1}{|c|}{ Authors } & \multicolumn{1}{c|}{ Indicator - innovation } \\
\hline $\begin{array}{l}\text { D’Angelo, Ma- } \\
\text { jocchi, Zucchella, } \\
\text { and Buck (2013), } \\
\text { Funk (2014), } \\
\text { Zhu, He, and Liu } \\
\text { (2014) }\end{array}$ & \\
\hline $\begin{array}{l}\text { He and Wong } \\
\text { (2012), Tan, } \\
\text { Shao, and Li } \\
(2013)\end{array}$ & Innovation performance \\
\hline $\begin{array}{l}\text { Morrison, Rabel- } \\
\text { lotti, and Zirulia } \\
\text { (2013) }\end{array}$ & Innovativeness \\
\hline $\begin{array}{l}\text { Bindroo et al. } \\
\text { (2012) }\end{array}$ & $\begin{array}{l}\text { The variation in the different } \\
\text { innovation outcomes }\end{array}$ \\
\hline $\begin{array}{l}\text { Bouncken and } \\
\text { Kraus (2013) }\end{array}$ & $\begin{array}{l}\text { Radical innovation or ex- } \\
\text { tremely novel revolutionary } \\
\text { innovation }\end{array}$ \\
\hline $\begin{array}{l}\text { Casanueva et al. } \\
\text { (2013) }\end{array}$ & Product innovation \\
\hline $\begin{array}{l}\text { Daddi, Tessitore, } \\
\text { and Frey (2012) }\end{array}$ & Eco-innovation \\
\hline $\begin{array}{l}\text { Tavassoli and } \\
\text { Carbonara (2014) }\end{array}$ & Region's innovation \\
\hline $\begin{array}{l}\text { Wang and Lin } \\
(2013)\end{array}$ & Technological innovation \\
\hline
\end{tabular}

The study by Funk (2014) develops and tests a theory of how company's local environments influence the ability to generate innovations. Case study shows that inefficient networks are beneficial as they create and sustain diversity internally even when proximity to industry peers decreases.

The article by Casanueva et al. (2013) is designed to analyse the relation between social networks and innovation in mature geographical clusters. A wide range of ties was analyzed in order to understand how they impact the transition of tacit and explicit knowledge. The results show that a central position is significant in product innovation while the role of structural holes is weaker. Correlation and regression analysis was applied to compare the variables in a single cluster of 52 SMEs. The authors suggest 
that further studies can be complemented by the results of recent study and longitudinal studies can follow to examine how different relationships evolve and see the causality between the variables. More detailed study could follow as well taking interactions between the variables in recent study as the independent variables.

Knowledge is ascribed to the third group of indicators. This indicator is one of the most specific attributes in clusters' nature. Needless to say, it also implicate positive and negative fetures depending on the strategies of usage (see Table 4).

Table 4. 3rd group of indicators as viewed by scholars in scientific literature - knowledge

\begin{tabular}{|l|l|}
\hline \multicolumn{1}{|c|}{ Authors } & \multicolumn{1}{c|}{ Indicator - knowledge } \\
\hline $\begin{array}{l}\text { Bouncken and } \\
\text { Kraus (2013) }\end{array}$ & $\begin{array}{l}\text { Sharing knowledge with the } \\
\text { partner, learning from the part- } \\
\text { ner and technological uncertain- } \\
\text { ty. Cooperation }\end{array}$ \\
\hline $\begin{array}{l}\text { Lai et al. } \\
\text { (2014) }\end{array}$ & $\begin{array}{l}\text { Corporate knowledge manage- } \\
\text { ment }\end{array}$ \\
\hline Maskell (2014) & $\begin{array}{l}\text { Can be acquired through pipe- } \\
\text { lines, listening posts, crowd- } \\
\text { sourcing and trade fairs. }\end{array}$ \\
\hline $\begin{array}{l}\text { Morrison et al. } \\
\text { (2013) }\end{array}$ & $\begin{array}{l}\text { Global pipelines, knowledge } \\
\text { endowment and internal } \\
\text { knowledge transfer }\end{array}$ \\
\hline $\begin{array}{l}\text { Stanko and } \\
\text { Olleros (2013) }\end{array}$ & $\begin{array}{l}\text { Three dimensions are studied: } \\
\text { the outsourcing of innovation } \\
\text { activities, geographic clustering } \\
\text { of companies and mobility of } \\
\text { labour. }\end{array}$ \\
\hline $\begin{array}{l}\text { Tavassoli and } \\
\text { Carbonara } \\
\text { (2014) }\end{array}$ & $\begin{array}{l}\text { The variety and intensity of } \\
\text { internal and external knowledge }\end{array}$ \\
\hline $\begin{array}{l}\text { Feldman } \\
\text { (2014) }\end{array}$ & $\begin{array}{l}\text { Mechanisms and institutions } \\
\text { promoting the creation of useful } \\
\text { knowledge. }\end{array}$ \\
\hline
\end{tabular}

Lai, Hsu, F. J. Lin, Chen, and Y. H. Lin (2014) correlation and regression analysis is applied to investigate the relationships between corporate knowledge management and innovation performance (Lai et al., 2014). The study suggests that industry clustering has positive effect on corporate innovation performance and corporate knowledge.

A comprehensive framework is applied by Maskell (2014) to allow the discussion of the approaches available to companies engaged in globally extended learning. The article explores knowledge and solutions from geographically and relationally remote sources can be acquired through pipelines, listening posts, crowdsourcing and trade fairs.

Correlation and regression analysis enable to find the relation showing that both the variety and intensity of internal and external knowledge matter for region's innovation (Tavassoli \& Carbonara, 2014).

The fourth group of indicators is formed as networking. This indicator is viewed through different perspectives by scholars and can add to other indicators respectively (see Table 5).

Table 5. 4th group of indicators as viewed by scholars in scientific literature - networking (composed by authors)

\begin{tabular}{|l|l|}
\hline \multicolumn{1}{|c|}{ Authors } & \multicolumn{1}{c|}{ Indicator - networking } \\
\hline $\begin{array}{l}\text { D'Angelo et al. } \\
\text { (2013) }\end{array}$ & One of the key resources \\
\hline Giuliani (2013) & Different kinds of networking \\
\hline $\begin{array}{l}\text { He and Wong } \\
(2012)\end{array}$ & Local networking \\
\hline Li et al. (2013) & $\begin{array}{l}\text { Network relational characteris- } \\
\text { tics, such as tie strength, tie } \\
\text { stability, tie quality were taken } \\
\text { into consideration for compa- } \\
\text { nies' performance. }\end{array}$ \\
\hline $\begin{array}{l}\text { Lorenzen and } \\
\text { Mudambi } \\
\text { (2013) }\end{array}$ & $\begin{array}{l}\text { Personal relationships - social } \\
\text { network. }\end{array}$ \\
\hline $\begin{array}{l}\text { Tan et al. } \\
\text { (2013) }\end{array}$ & $\begin{array}{l}\text { Ties between companies and } \\
\text { colleges, ties between compa- } \\
\text { nies and industrial associations, } \\
\text { and ties between companies }\end{array}$ \\
\hline $\begin{array}{l}\text { Wang and Lin } \\
\text { (2013) }\end{array}$ & Inter-firm relation \\
\hline $\begin{array}{l}\text { D'Este et al. } \\
\text { (2013) }\end{array}$ & $\begin{array}{l}\text { Collaboration between universi- } \\
\text { ties and industry }\end{array}$ \\
\hline
\end{tabular}

The main concern of the study by Li et al. (2013) is the impact of spatial relationships on firm performance. Industry cluster in China was taken for case analysis, in -cluster and extra cluster ties were accounted for performance of companies. Network relational characteristics, such as tie strength, tie stability, tie quality were taken into consideration for companies' performance. The results show that distant linkages should be development to avoid lock-in and entropic deterioration.

Lorenzen and Mudambi (2013) add to cluster theory a broader understanding by including linkages in the form of personal relationships. This theory of social network allows forming testable propositions. Local spillowers has the 
best potential in global linkages with decentralized network structures. There are two contrasting points regarding this theory: clusters may have potential for in-depth (when clusters are linked to the global economy by decentralized pipelines) or in-breadth (when clusters are linked through decentralized personal relationships) catch-up in industries and technologies. The theoretical prepositions are illustrated by case studies in two emerging economies in India.

Tan et al. (2013). The main interest of the study is competitive advantage which is required for companies which at the same time are given the competitive pressures for differentiation and the institutional pressures of conformity (Tan et al., 2013). Measures, such as innovative performance, ties between companies and colleges, ties between companies and industrial associations, and ties between companies are tested. Here, peripheral companies tend to be isomorphic institutionally and competitevily, while central companies avoid institutional conformity and competitive differentiation.

The fith group - financial indicators helps to submit some financial material and to make calculations on that (see Table 6).

Boschma et al. (2013) analyse the emergence of new industries in 50 Spanish regions at the NUTS 3 level in 30 years period to see how regions diversify over time. Econometric evidence is provided after Spanish regions are analysed in terms of capability distance between new export products and existing export products. The results show that regions tend to follow the industrial structure trends rather than that of national industrial structure. This assumption suggests that regional capabilities may show the tendency of new industries to be developed in regions for proximity really matters in this case.

Foreign direct investment (FDI) activities are taken into account in examination of multinational companies and their behavior regarding global cluster networks and global city-region networks (Bathelt \& Li, 2014). It is suggested that multinational cluster companies are more likely to set up new foreign affiliates in other, similarly specialized clusters to keep up with global industry dynamics. Vice-versa, nonclustered companies would avoid to invest in clusters. Another hypothesis, that was generally supported by the investigation of 299 FDI cases from Canada to China, considers that cluster networks are generating cnnections that are horizontal and vertical in character and thus shape global city-region networks.
Table 6. 5th group of indicators as viewed by scholars in scientific literature - financial indicators (composed by authors)

\begin{tabular}{|c|c|c|}
\hline $\begin{array}{l}\text { Financial } \\
\text { indicator }\end{array}$ & Authors & Main points \\
\hline Export & $\begin{array}{l}\text { Boschma et } \\
\text { al. (2013), } \\
\text { D’Angelo et } \\
\text { al. (2013), } \\
\text { Daddi et al. } \\
\text { (2012) }\end{array}$ & $\begin{array}{l}\text { Capability dis- } \\
\text { tance between } \\
\text { new export } \\
\text { products and } \\
\text { existing export } \\
\text { products; } \\
\text { The influence on } \\
\text { export perfor- } \\
\text { mance of key } \\
\text { resources. }\end{array}$ \\
\hline $\begin{array}{l}\text { Market effi- } \\
\text { ciency }\end{array}$ & $\begin{array}{l}\text { Alcacer and } \\
\text { Chuang } \\
(2014)\end{array}$ & $\begin{array}{l}\text { One of three } \\
\text { points that both } \\
\text { supply and de- } \\
\text { mand sides of } \\
\text { agglomeration } \\
\text { economies must } \\
\text { be examined. }\end{array}$ \\
\hline $\begin{array}{l}\text { Returns / prof- } \\
\text { it }\end{array}$ & $\begin{array}{l}\text { Dobusch and } \\
\text { Schussler } \\
\text { (2013), } \\
\text { Stanko and } \\
\text { Olleros } \\
\text { (2013), To- } \\
\text { katli (2013) }\end{array}$ & $\begin{array}{l}\text { Increasing re- } \\
\text { turns; } \\
\text { Profitability; } \\
\text { Profit making or } \\
\text { capital accumu- } \\
\text { lation }\end{array}$ \\
\hline $\begin{array}{l}\text { Foreign direct } \\
\text { investment } \\
\text { (FDI) }\end{array}$ & $\begin{array}{l}\text { Bathelt and } \\
\text { Li (2014) }\end{array}$ & $\begin{array}{l}\text { Foreign direct } \\
\text { investment (FDI) } \\
\text { activities are } \\
\text { taken into ac- } \\
\text { count in exami- } \\
\text { nation of multi- } \\
\text { national } \\
\text { companies }\end{array}$ \\
\hline $\begin{array}{l}\text { External in- } \\
\text { vestments }\end{array}$ & $\begin{array}{l}\text { Isaksen } \\
(2015)\end{array}$ & $\begin{array}{l}\text { External invest- } \\
\text { ments often } \\
\text { needed for thin } \\
\text { regions. }\end{array}$ \\
\hline Trade quotas & $\begin{array}{l}\text { Smith, Pick- } \\
\text { les, Bucek, } \\
\text { Pastor, and } \\
\text { Begg (2014) }\end{array}$ & $\begin{array}{l}\text { Struggling with } \\
\text { the removal of } \\
\text { trade quotas }\end{array}$ \\
\hline Production & $\begin{array}{l}\text { Daddi et al. } \\
\text { (2012) }\end{array}$ & $\begin{array}{l}\text { The amount of } \\
\text { production }\end{array}$ \\
\hline
\end{tabular}

The study by Smith et al. (2014) is designed to show the development of clothing industry in Eastern Europe for in recent years it has been struggling with the removal of trade quotas, increasing competitive pressures and the global economic crisis

The sixth group - investment indicators work on deeper investigation of external and internal investment (see Table 7). 
Table 7. 6th group of indicators as viewed by scholars in scientific literature - investment indicators (composed by authors)

\begin{tabular}{|l|l|l|}
\hline \multicolumn{1}{|c|}{$\begin{array}{c}\text { Investment } \\
\text { indicator }\end{array}$} & \multicolumn{1}{|c|}{ Authors } & \multicolumn{1}{c|}{ Main points } \\
\hline $\begin{array}{l}\text { Research and } \\
\text { development } \\
\text { (R\&D) }\end{array}$ & $\begin{array}{l}\text { Castellani } \\
\text { et al. (2013), } \\
\text { D'Agostino, } \\
\text { Laursen, and } \\
\text { Santangelo } \\
\text { (2013) }\end{array}$ & $\begin{array}{l}\text { International } \\
\text { research and } \\
\text { development } \\
\text { (R\&D) invest- } \\
\text { ments; High- } \\
\text { tech R\&D and } \\
\text { medium or low } \\
\text { R\&D. }\end{array}$ \\
\hline Upgrading & $\begin{array}{l}\text { Tokatli } \\
\text { (2013), Zhu et } \\
\text { al. (2014) }\end{array}$ & $\begin{array}{l}\text { Capital accu- } \\
\text { mulation can } \\
\text { differ depend- } \\
\text { ing on compa- } \\
\text { nies upgrade; } \\
\text { Products up- } \\
\text { grade }\end{array}$ \\
\hline
\end{tabular}

The importance of geographical proximity is discussed by Castellani et al. (2013) in the article for multinational enterprises (MNEs) regarding to international research and development (R\&D) investments. Gravity model of trade was used to see how geographical distance impacts $R \& D$ investments. The results show that geographic distance has a lower negative impact on the probability of setting up R\&D than manufacturing plants, while once measures of institutional proximity are accounted for, MNEs are equally likely to set up $\mathrm{R} \& \mathrm{D}$ labs in nearby or in more remote locations.

D'Agostino et al. (2013) study the relationship between a region's home and foreign investments in R\&D that affects home's regional knowledge production. The findings suggest that regions of high income would have advantage in high-tech R\&D while emerging economies have an advantage in medium or low R\&D.

The seventh group - government indicator help to identify the impact of governmental deccisions on clusters' performance (see Table 8).

The main concern of the study by Corredoira and McDermott (2014) is how do multinational corporation subsidiaries and local institutions help or hinder emerging market suppliers to upgrade their capabilities. Field work and unique survey data of Argentine auto parts supplier was combined to reveal that process upgrading improves significantly when suppliers have ties to institutions that improve access to a variety of experiential knowledge. Study shows that suppliers benefit from multinational corporation subsidiaries in cases when they collaborate with non-market institutions and are able to recombine experiential knowledge with standards gained from the subsidiaries.

Table 8. 7th group of indicators as viewed by scholars in scientific literature - government indicators

\begin{tabular}{|c|l|l|}
\hline $\begin{array}{c}\text { Government } \\
\text { indicator }\end{array}$ & \multicolumn{1}{|c|}{ Authors } & \multicolumn{1}{|c|}{ Main points } \\
\hline Subsidiaries & $\begin{array}{l}\text { Corredoira } \\
\text { and McDer- } \\
\text { mott (2014) }\end{array}$ & $\begin{array}{l}\text { How do multina- } \\
\text { tional corpora- } \\
\text { tion subsidiaries } \\
\text { and local institu- } \\
\text { tions help or } \\
\text { hinder emerging } \\
\text { market suppliers } \\
\text { to upgrade their } \\
\text { capabilities? }\end{array}$ \\
\hline Policies & $\begin{array}{l}\text { Crespo et al. } \\
\text { (2014) }\end{array}$ & $\begin{array}{l}\text { Policy-oriented } \\
\text { analysis }\end{array}$ \\
\cline { 2 - 4 } & Ketels (2013) & $\begin{array}{l}\text { Policies are } \\
\text { mostly focussed } \\
\text { on strengthening } \\
\text { existing agglom- } \\
\text { erations }\end{array}$ \\
\cline { 2 - 4 } & $\begin{array}{l}\text { Nathan and } \\
\text { Overman }\end{array}$ & $\begin{array}{l}\text { Spatial economy } \\
\text { and industrial } \\
\text { policy interven- } \\
\text { tions. }\end{array}$ \\
\hline
\end{tabular}

Ketels (2013) study is designed to review recent researches on competitiveness and clusters for regions and regional policy. The findings show that policies are mostly focussed on strengthening existing agglomerations rather than establishing new ones.

Nathan and Overman (2013) review the development of cluster policies and the evolution of cluster notion. Authors suggest how governments should pay careful attention to the spatial economy and industrial policy interventions.

The eighth group - resource indicators reveals important information on clusters' properties (see Table 9).

D'Angelo et al. (2013) study regional and global pathways to internationalization for SMEs to examine the influence on export performance of key resources, such as innovation, human resource management, networking and the company's experience. Correlation and regression model is applied to compare the variables and the results show that SMEs' export performance varies depending on the geographic scope of internationalization. 
Table 9. 8th group of indicators as viewed by scholars in scientific literature - resource indicators

\begin{tabular}{|c|c|c|}
\hline $\begin{array}{l}\text { Resource } \\
\text { indicator }\end{array}$ & Authors & Main points \\
\hline $\begin{array}{l}\text { Company's } \\
\text { experience }\end{array}$ & $\begin{array}{l}\text { D'Angelo } \\
\text { et al. (2013) }\end{array}$ & $\begin{array}{l}\text { One of the key } \\
\text { resources }\end{array}$ \\
\hline Growth & $\begin{array}{l}\text { Jiang and } \\
\text { Miao (2015) }\end{array}$ & $\begin{array}{l}\text { Natural cities } \\
\text { evolve in nonlin- } \\
\text { ear manners at } \\
\text { spatial and tem- } \\
\text { poral dimen- } \\
\text { sions. }\end{array}$ \\
\hline Dimensions & $\begin{array}{l}\text { Morrison } \\
\text { et al. (2013) }\end{array}$ & $\begin{array}{l}\text { Fostering the } \\
\text { growth of clus- } \\
\text { ters }\end{array}$ \\
\hline Dimensions & $\begin{array}{l}\text { Wang and } \\
\text { Lin (2013) }\end{array}$ & $\begin{array}{l}\text { Firm attributes, } \\
\text { firm size and } \\
\text { technological } \\
\text { intensity }\end{array}$ \\
\hline Cluster's size & $\begin{array}{l}\text { De Vaan, } \\
\text { Boschma, } \\
\text { and Frenken } \\
(2013)\end{array}$ & $\begin{array}{l}\text { Clustering be- } \\
\text { comes positive } \\
\text { after a cluster } \\
\text { reaches critical } \\
\text { size }\end{array}$ \\
\hline Cluster's size & $\begin{array}{l}\text { Daddi et al. } \\
(2012)\end{array}$ & $\begin{array}{l}\text { Number of en- } \\
\text { terprises }\end{array}$ \\
\hline $\begin{array}{l}\text { Path } \\
\text { dependence }\end{array}$ & $\begin{array}{l}\text { Dobusch } \\
\text { and } \\
\text { Schussler } \\
(2013)\end{array}$ & $\begin{array}{l}\text { Positive feed- } \\
\text { back of path de- } \\
\text { pendence }\end{array}$ \\
\hline $\begin{array}{l}\text { Path } \\
\text { dependence }\end{array}$ & $\begin{array}{l}\text { Isaksen } \\
(2015)\end{array}$ & $\begin{array}{l}\text { Regional path } \\
\text { dependent indus- } \\
\text { trial develop- } \\
\text { ment is often } \\
\text { characterized by } \\
\text { lock-in effects }\end{array}$ \\
\hline $\begin{array}{l}\text { Cluster } \\
\text { formation }\end{array}$ & $\begin{array}{l}\text { Letaifa and } \\
\text { Rabeau } \\
(2013)\end{array}$ & $\begin{array}{l}\text { Naturally formed } \\
\text { clusters with } \\
\text { private entrepre- } \\
\text { neurial initiatives } \\
\text { or created by } \\
\text { economic poli- } \\
\text { cies. }\end{array}$ \\
\hline Labour & $\begin{array}{l}\text { Carswell } \\
\text { and De } \\
\text { Neve (2013) }\end{array}$ & $\begin{array}{l}\text { Information on } \\
\text { occupations, } \\
\text { incomes, migra- } \\
\text { tion patterns, } \\
\text { caste, education } \\
\text { and asset owner- } \\
\text { ship. }\end{array}$ \\
\hline $\begin{array}{l}\text { Human } \\
\text { resource } \\
\text { management }\end{array}$ & $\begin{array}{l}\text { D'Angelo } \\
\text { et al. (2013) }\end{array}$ & $\begin{array}{l}\text { One of the key } \\
\text { resources }\end{array}$ \\
\hline Employment & $\begin{array}{l}\text { Daddi et al. } \\
(2012)\end{array}$ & Human resources \\
\hline
\end{tabular}

Regional path dependent industrial development is often characterized by lock-in effects while dealing with changes, such as path renewal and path creation (Isaksen, 2015). The study suggests that thin regions often need external investments to achieve path renewal and path creation.

Carswell and De Neve (2013) emphasize the importance of labour and highlights that it receives less attention from scholars than it deserves. Labour's multiple and everyday forms of agency are seen as helping to shape local developments of global capitalism as well as producing transformative effects on workers' livelihoods, social relations and reproductive capacities. The research was carried out in one Indian city and its rural hinterland and took more than a year. Quantitative and qualitative information was used for the study and different methods, such as case studies, focus group discussions, indepth interviews with large number of garment workers, labour contractors, supervisors and company owners. Participation observation research was carried out in a small garment unit and overall study took 300 garment workers collecting information on occupations, incomes, migration patterns, caste, education and asset ownership.

Table 10. 9th group of indicators as viewed by scholars in scientific literature - sustainability indicators

\begin{tabular}{|l|l|l|}
\hline $\begin{array}{c}\text { Sustainability } \\
\text { indicator }\end{array}$ & \multicolumn{1}{|c|}{ Authors } & \multicolumn{1}{c|}{ Main points } \\
\hline Environment & $\begin{array}{l}\text { Longoni } \\
\text { and Cag- } \\
\text { liano } \\
(2015), \\
\text { Wang and } \\
\text { Lin (2013), } \\
\text { Wang, Qiu, } \\
\text { and Swal- } \\
\text { low (2014), } \\
\text { Zhang and } \\
\text { Huang } \\
\text { (2012) }\end{array}$ & $\begin{array}{l}\text { Environment } \\
\text { operations strat- } \\
\text { egies; } \\
\text { Regional envi- } \\
\text { ronment; } \\
\text { Fresh food ac- } \\
\text { cessibility; } \\
\text { Major business } \\
\text { environment } \\
\text { changes on } \\
\text { manufacturing } \\
\text { outsourcing. }\end{array}$ \\
\hline $\begin{array}{l}\text { Social sustaina- } \\
\text { bility }\end{array}$ & $\begin{array}{l}\text { Longoni } \\
\text { and Cag- } \\
\text { liano (2015) }\end{array}$ & $\begin{array}{l}\text { social sustaina- } \\
\text { bility is becom- } \\
\text { ing key competi- } \\
\text { tive priority for } \\
\text { companies }\end{array}$ \\
\hline
\end{tabular}

The ninth group of indicators, which is sustainability reveals how important it is to draw 
attention to environmental and social issues (see Table 10). The importance of energy security and sustainability is often emphasized by scholars (Tvaronavičienè et al., 2015; Kendiukhov \& Tvaronavičienè, 2017) although they rarely relate it to clusters' activities.

Longoni and Cagliano (2015) have designed an article to examine how environment and social sustainability are integrated in operations strategies for they are becoming key competitive priorities for companies. The findings suggest that traditional operations strategies are slightly modified for market-oriented and capabilityoriented strategies need to be supplemented with environmental and social sustainability issues.

The study is designed to research how community gardens and farmer's gardens help to improve fresh food accessibility (Wang et al., 2014). The results show that community gardens tend to cluster with supermarkets.

Zhang and Huang (2012) in the study concern supply chain strategy, aiming to investigate the impacts of the major business environment changes on manufacturing outsourcing in China. The findings show that the coastal part of China is attractive for products for industrial clusters that are formed there and efficient logistics service.

\section{Conclusions}

Clusters maintain the position of interest with scholars during the recent years and the number of scientific researches in this area keeps on growing. Different aspects are being analysed by scholars and new topics are emerging. Clusters represent a complex form of organization, in which social ties (the community), productive networks of local firms, and the web of local institutions and collective agents form a cooperative and competitive density. Clusters are a characteristic phenomenon in local or regional markets, but their function is to build a competitive advantage for cluster members on a larger scale - not only national but international.

Traditional bibliometric technique was chosen to identify the trends in cluster literature. 50 articles were selected according to the times they were cited which allowed systemizing the aspects of the research and making valuable observations. The findings suggest that cluster performance evaluation should include a number of different indicators which view different aspects of cluster activities to get the best result and enable making suggestions of how the cluster execu- tion could be improved. A system of indicators which should get the most attention in cluster research was composed identifying exceptionally important points to discuss and include in the next research. As for being very extensive from the indicators viewpoint the literature analysis allows researches to create an adequate model for clusters' performance evaluation on behalf of the system of indicators that are suggested in this paper. Clusters' performance evaluation is a very important step for everyone who is concerned in clusters' improvement and further development of successful clusters' activities.

The articles for the analysis were selected according to the number that they were cited. The limitation of the research is that these articles might be viewed as older than that of the recent years. That put the researches under an obligation to update the research periodically. Literature analysis suggests that the system of indicators for evaluation of clusters' performance should be complex and involve a great number of different aspects to make it detailed, comprehensive and objective. All the indicators that are mentioned in previous tables are recommended to be used for clusters' performance evaluation. These indicators should be viewed through different angles, categorized according to their general features and posible dimentions, and the values should be applied regarding to their nature. This paper is composed as a recommendation for further development of clusters' evaluation model and its final formulation. In further research these indicators should be turned into descriptive statements or questions for deeper understanting of the essentials.

Very often clusters' coordinators face a problem of how to evaluate the performance of clusters on the national level and how to make them attractive on the global scale. In the national level clusters usually are not able to compare their performance for there is no system created to serve this purpose. The close analysis of the indicators of cluster performance would enable cluster evaluation tool formation for cluster performance evaluation in national level. These indicators can work as a guide for monitoring cluster activities and evaluating their performance for creating an action plan which could be very effective in working on strategy.

\section{References}

Alcacer, J., \& Chung, W. (2014). Location strategies for agglomeration economies. Strategic Management, 35(12), 1749-1761. https://doi.org/10.1002/smj.2186 
Basile, R., Benfratello, L., \& Castellani, D. (2013). Geoaditive models for regional count data: an application to industrial location. Geographic Analysis, 45(1), 2848. https://doi.org/10.1111/gean.12001

Bathelt, H., \& Li, P. F. (2014). Global cluster networksforeign direct investment flows from Canada to China. Journal of Economic Geography, 14(1). https://doi.org/10.1093/jeg/lbt005

Bindroo, V., Mariadoss, BJ., \& Pillai, R. G. (2012). Customer clusters as sources of ninovation-based competitive advantage. Journal of International Marketing, 20(3), 17-33. https://doi.org/10.1509/jim.11.0159

Boschma, R., Minondo, A., \& Navarro, M. (2013). The emergence of new industries at the regional revel in spain: a proximity approach based on product relatedness. Economic Geography, 89(1), 29-51. https://doi.org/10.1111/j.1944-8287.2012.01170.x

Bouncken, R. B., \& Kraus, S. (2013). Innovation in knowledge-intensive industries: the double-edged sword of coopetition. Journal of Business Research, 66(10), 2060-2070.

https://doi.org/10.1016/j.jbusres.2013.02.032

Carswell, G. (2013). Dalits and local labour markets in rural India: experiences from the Tiruppur textile region in Tamil Nadu. Transactions of the Institute of British Geographers, 38(2), 325-338. https://doi.org/10.1111/j.1475-5661.2012.00530.x

Carswell, G., \& De Neve, G. (2013). Labouring for global markets: conceptualising labour agency in global production networks. Geoforum, 44, 62-70.

https://doi.org/10.1016/j.geoforum.2012.06.008

Casanueva, C., Castro, I., \& Galan, J. L. (2013). Informational networks and innovation in mature industrial clusters. Journal of Business Research, 66(5), 603613. https://doi.org/10.1016/j.jbusres.2012.02.043

Castellani, D., Jimenez, A., \& Zanfei, A. (2013). How remote are R\&D labs? Distance factors and international innovative activities. Journal of International Business Studies, 44(7), 649-675. https://doi.org/10.1057/jibs.2013.30

Corredoira, R. A., \& McDermott, G. A. (2014). Adaptation, bridging and firm upgrading: how non-market institutions and MNCs facilitate knowledge recombination in emerging markets. Journal of International Business Studies, 45(6). https://doi.org/10.1057/jibs.2014.19

Crane, A., Palazzo, G., Spence, L. J., \& Matten, D. (2014). Contesting the value of "Creating shared value". California Management Review, 56(2), 130-149. https://doi.org/10.1525/cmr.2014.56.2.130

Crespo, J., Suire, R., \& Vicente, J. (2014). Lock-in or lockout? How structural properties of knowledge networks affect regional resilience, Journal of Economic Geography, 14(1), 199-219. https://doi.org/10.1093/jeg/lbt006

D’Agostino, L. M., Laursen, K., Santangelo, G. D. (2013). The impact of $R \& D$ offshoring on the home knowledge production of OECD investing regions. Journal of Economic Geography, 13(1), 145-175. https://doi.org/10.1093/jeg/lbs012

D’Angelo, A., Majocchi, A., Zucchella, A., \& Buck, T. (2013). Geographical pathways for SME internationalization: insights from an Italian sample. International Marketing Review, 30(2), 80-105. https://doi.org/10.1108/02651331311314538

Dobrovolskienė, N., Tvaronavičienė, M., \& Tamošiūniené, R. (2017). Tackling projects on sutainability: a
Lithuanian case study. Entrepreneurship and Sustainability Issues, 4(4), 477-488.

https://doi.org/10.9770/jesi.2017.4.4(6)

D'Este, P., Guy, F., \& Iammarino, S. (2013). Shaping the formation of university-industry research collaborations: what type of proximity does really matter?. Journal of Economic Geography, 13(4), 537-558. https://doi.org/10.1093/jeg/lbs010

Daddi, T., Tessitore, S., \& Frey, M. (2012). Eco-innovation and competitiveness in industrial clusters. International Journal of Technology Management, 58(1-2), 49-63.

De Vaan, M., Boschma, R., \& Frenken, K. (2013). Clustering and firm performance in project-based industries: the case of the global video game industry, 19722007. Journal of Economic Geography, 13(6), 965991. https://doi.org/10.1093/jeg/lbs038

Dobusch, L., \& Schussler, E. (2013). Theorizing path dependence: a review of positive feedback mechanisms in technology markets, regional clusters, and organizations. Industrial and Corporate Change, 22(3), 617647. https://doi.org/10.1093/icc/dts029

Fallah, B., Partridge, M. D., \& Rickman, D. S. (2014). Geography and high-tech employment growth in US counties. Journal of Economic Geography, 14(4), 683-720. https://doi.org/10.1093/jeg/lbt030

Feldman, M. P. (2014). The character of innovative places: entrepreneurial strategy, economic development, and prosperity. Small Business Economics, 43(1), 9-20. https://doi.org/10.1007/s11187-014-9574-4

Funk, R. J. (2014). Making the most of where you are: geography, networks and innovation in organizations. Academy of Management Journal, 57(1). https://doi.org/10.5465/amj.2012.0585

Fuschi, D. L., \& Tvaronavičienė, M. (2016). A network based business partnership model for SMEs management. Entrepreneurship and Sustainability Issues, 3(3), 282-289. https://doi.org/10.9770/jesi.2016.3.3(5)

Giuliani, E. (2013). Clusters, networks and firms' product success: an empirical study. Management Decision, 51(6), 1135-1160. https://doi.org/10.1108/MD-01-2012-0010

He, Z. L., \& Wong, P. K. (2012). Reaching out and reaching within: a study of the relationship between innovation collaboration and innovation performance. Industry and Innovation, 19(7), 539-561. https://doi.org/10.1080/13662716.2012.726804

Hervas-Oliver, J. L., Gonzalez, G., Caja, P., \& SempereRipoll, F. (2015). Clusters and industrial districts: Where is the literature going? Identifying emerging sub-fields of research. European Planning Studies, 23(9), 1827-1872. https://doi.org/10.1080/09654313.2015.1021300

Helsley, R. W., \& Strange, W. C. (2014). Coagglomeration, clusters, and the scale and composition of cities. Journal of Political Economy, 122(5), 1064-1093. https://doi.org/10.1086/676557

Isaksen, A. (2015). Industrial development in thin regions: trapped in path extension?. Journal of Economic Geography, 15(3), 585-600. https://doi.org/10.1093/jeg/lbu026

Jiang, B., \& Miao, Y. F. (2015). The evolution of natural cities from the perspective of location-based social media. Professional Geographer, 67(2), 295-306. https://doi.org/10.1080/00330124.2014.968886

Kendiukhov, I., \& Tvaronavičienè, M. (2017). Managing innovations in sustainable economic growth. Market- 
ing and Management of Innovations 3, 33-42. https://doi.org/10.21272/mmi.2017.3-03

Ketels, C. (2013). Recent research on competitiveness and clusters: what are the implications for regional policy?. Cambridge Journal of Regions Economy and Society, 6(2), 269-284. https://doi.org/10.1093/cjres/rst008

Lai, Y. L., Hsu, M. S., Lin, F. J., Chen, Y. M., \& Lin, Y. H. (2014). The effects of industry cluster knowledge management on innovation performance. Journal of Business Research, 67(5), 34-739. https://doi.org/10.1016/j.jbusres.2013.11.036

Lazzeretti, L., Sedita, S. R., \& Caloffi, A. (2014). Founders and disseminators of cluster research. Journal of Economic Geography, 14(1), 21-43. https://doi.org/10.1093/jeg/lbs053

Letaifa, B., \& Rabeau, Y. (2013). Too close to collaborate? How geographic proximity could impede entrepreneurship and innovation. Journal of Business Research, 66(10), 2071-2078. https://doi.org/10.1016/j.jbusres.2013.02.033

Li, W., Veliyath, R., \& Tan, J. (2013). Network characteristics and firm performance: an examination of the relationships in the context of a cluster. Journal of Small Business Management, 51(1), 1-22. https://doi.org/10.1111/j.1540-627X.2012.00375.x

Longoni, A., \& Cagliano, R. (2015). Environmental and social sustainability priorities. Their integration in operations strategies. International Journal of Operations and Production Management, 35(2), 216-245. https://doi.org/10.1108/IJOPM-04-2013-0182

Lorenzen, M., \& Mudambi, R. (2013). Clusters, connectivity and catch-up: Bollywood and Bangalore in the global economy. Journal of Economic Geography, 13(3), 501-534. https://doi.org/10.1093/jeg/lbs017

Marshall, A. (1920). Principles of economics (revised Ed.). London: Macmillan, reprinted by Prometheus Books, 1st edn., 1890.

Maskell, P. (2014). Accessing remote knowledge-the roles of trade fairs, pipelines, crowdsourcing and listening posts. Journal of Economic Geography 14(5), 883902. https://doi.org/10.1093/jeg/lbu002

Monni, S., Palumbo, F., \& Tvaronavičienè, M. (2017). Cluster performance: an attempt to evaluate the Lithuanian case. Entrepreneurship and Sustainability Issues, 5(1), 43-57. https://doi.org/10.9770/jesi.2017.5.1(4)

Morrison, A., Rabellotti, R., \& Zirulia, L. (2013). When do global pipelines enhance the diffusion of knowledge in clusters?. Economic Geography, 89(1), 77-96. https://doi.org/10.1111/j.1944-8287.2012.01167.x

Nathan, M., \& Overman, H. (2013). Agglomeration, clusters, and industrial policy. Oxford Review of Economic Policy, 29(2), 383-404. https://doi.org/10.1093/oxrep/grt019

Porter, M. E. (1990). The competitive advantage of nations. New York: Free Press. https://doi.org/10.1007/978-1-349-11336-1

Prause, G., \& Atari, S. (2017). On sustainable production networks for Industry 4.0. Entrepreneurship and Sustainability Issues, 4(4), 421-431. https://doi.org/10.9770/jesi.2017.4.4(2)

Razminienè, K., \& Tvaronavičienè, M. (2017). Economic globalization and its impacts on clustering. Terrra Economicus, 15(2), 109-121.

Schmitt, A., \& Van Biesebroeck, J. (2013). Proximity strategies in outsourcing relations: the role of geograph- ical, cultural and relational proximity in the European automotive industry. Journal of International Business Studies, 44(5), 475-504.

https://doi.org/10.1057/jibs.2013.10

Smith, A., Pickles, J., Bucek, M., Pastor, R., \& Begg, B. (2013). The political economy of global production networks: regional industrial change and differential upgrading in the East European clothing industry. Journal of Economic Geography, 14(6), 1023-1051. https://doi.org/10.1093/jeg/lbt039

Stanko, M. A., \& Olleros, X. (2013). Industry growth and the knowledge spillover regime: does outsourcing harm innovativeness but help profit?. Journal of Business Research, 66(10), 2007-2016. https://doi.org/10.1016/j.jbusres.2013.02.026

Tan, J., Shao, Y. F., \& Li, W. (2013). To be different, or to be the same? An exploratory study of isomorphism in the cluster. Journal of Business Venturing, 28(1), 8397. https://doi.org/10.1016/j.jbusvent.2012.02.003

Tanner, A. N. (2014). Regional branching reconsidered: emergence of the fuel cell industry in European regions. Economic Geography, 90(4), 403-427. https://doi.org/10.1111/ecge.12055

Tavassoli, S., \& Carbonara, N. (2014). The role of knowledge variety and intensity for regional innovation. Small Business Economics, 43(2), 493-509. https://doi.org/10.1007/s11187-014-9547-7

Tokatli, N. (2013). Toward a better understanding of the apparel industry: a critique of the upgrading literature. Journal of Economic Geography, 13(6), 993-1011. https://doi.org/10.1093/jeg/lbs043

Tvaronavičienè, M. (2017). Clusters, innovations and energy efficiency: if relantionship could be traced. Marketing and Management of Innovations, 2, 382-391. https://doi.org/10.21272/mmi.2017.2-35

Tvaronavičienè, M., Mačiulis, A., Lankauskienè, T., Raudeliūnienè, J., \& Dzemyda, I. (2015). Energy security and sustainable competitiveness of industry development. Economic Research, 28(1), 502-516.

Tvaronavičienè, M., \& Razminienè, K. (2017). Towards competitive regional development through clusters: approaches to their performance evaluation. Journal of Competitiveness, 9(4), 133-147. https://doi.org/10.7441/joc.2017.04.09

Tvaronavičienė, M., Razminienè, K., \& Piccinetti, L. (2015). Aproaches towards cluster analysis, economics \& sociology. Journal of Scientific Papers, 8(1), 19-27.

Wang, C. C., \& Lin, G. C. S. (2013). Dynamics of innovation in a globalizing china: regional environment, inter-firm relations and firm attributes. Journal of Economic Geography, 13(3), 397-418. https://doi.org/10.1093/jeg/lbs019

Wang, H. L., Qiu, F., \& Swallow, B. (2014). Can community gardens and farmers' markets relieve food desert problems? A study of Edmonton, Canada. Applied Geography, 55, 127-137. https://doi.org/10.1016/j.apgeog.2014.09.010

Yang, J., \& Černevičiūtè, J. (2017). Cultural and creative industries (CCI) and sustainable development: China's cultural industries clusters. Entrepreneurship and Sustainability Issues, 5(2), 231-242. https://doi.org/10.9770/jesi.2017.5.2(6)

Zhang, A., \& Huang, G. Q. (2012). Impacts of business environment changes on global manufacturing outsourcing in China. Supply Chain Management - an International Journal, 17(2), 138-151. https://doi.org/10.1108/13598541211212889 
Zheng, J. E. (2011). Creative industry clusters' and the "Entrepreneurial City" of Shanghai. Urban Studies, 48(16), 3561-3582.

https://doi.org/10.1177/0042098011399593
Zhu, S. J., He, C. F., \& Liu, Y. (2014). Going green or going away: environmental regulation, economic geography and firms' strategies in China's pollutionintensive industries. Geoforum, 55, 53-65.

https://doi.org/10.1016/j.geoforum.2014.05.004 